\title{
Range Finding Test (RFT) Cyperus rotundus L. dan Scirpus grossus sebagai Penelitian Pendahuluan dalam Pengolahan Limbah Cair Tempe
}

\author{
Marissa Olivia Damanik dan Ipung Fitri Purwanti \\ Departemen Teknik Lingkungan, Fakultas Teknik Sipil, Lingkungan dan Kebumian, Institut Teknologi \\ Sepuluh Nopember (ITS) \\ e-mail:purwanti@enviro.its.ac.id
}

\begin{abstract}
Abstrak-Tempe merupakan hasil fermentasi kedelai. Bahanbahan organik yang terkandung di dalam buangan industri tempe pada umumnya sangat tinggi. Senyawa-senyawa organik di dalam air buangan tersebut dapat berupa protein, karbohidrat, lemak dan minyak. Salah satu alternatif untuk memperbaiki air yang tercemar adalah dengan mengolahnya dengan fitotreatment menggunakan tanaman air. Uji Range Finding Test (RFT) merupakan tahap awal dalam rangkaian pengolahan limbah cair tempe menggunakan system reed bed. Adapun tujuan yang ingin dicapai dalam RFT ini adalah untuk mengetahui konsentrasi limbah cair tempe yang mana Cyperus rotundus $L$ dan Scirpus grossus masih bisa bertahan hidup. Konsentrasi maksimum yang mana tumbuhan masih bisa bertahan hidup ditunjukkan tidak terjadinya perubahan fisik (warna daun) tumbuhan. Selama 7 hari pengamatan, didapatkan kadar maksimum yang dapat ditolerir oleh Cyperus rotundus dan Scirpus grossus adalah $10 \%$ limbah rebusan, $10 \%$ limbah campuran dan $25 \%$ limbah rendaman.
\end{abstract}

Kata Kunci-Cyperus rotundus L, Scirpus grossus, fitotreatment, Limbah Cair Tempe.

\section{PENDAHULUAN}

$\mathrm{P}$ ROSES pembuatan tempe masih sangat tradisional dan banyak memakai tenaga manusia. Bahan baku utama yang digunakan adalah kedelai (Glycine spp). Konsumsi kedelai Indonesia pada tahun 2013 telah mencapai 7,8 kg/kap/tahun [1]. Limbah dari pembuatan tempe mempunyai kadar BOD sekitar 5.000-10.000 mg/L, COD 7.000-12.000 mg/L [2]. Bukan hanya itu, limbah cair pabrik tempe juga mengandung amoniak $\left(\mathrm{NH}_{3} \mathrm{~N}\right)$ bebas, nitrat $\left(\mathrm{NO}_{3} \mathrm{~N}\right)$ serta fosfat $\left(\mathrm{PO}_{4}\right)$ [3]

Jumlah pabrik tempe yang banyak dan sebagian besar mengambil lokasi di sekitar sungai ataupun selokan guna memudahkan proses pembuangan limbahnya, akan sangat mencemari lingkungan perairan di sekitarnya. Hal ini dapat terjadi karena belum adanya upaya pengolahan limbah. Limbah dibuang langsung ke badan air tanpa pengolahan terlebih dahulu, berpotensi menimbulkan kerusakan dan ketidakseimbangan biologis di alam. Oleh sebab itu penting untuk adanya proses pengolahan terlebih dahulu sebelum dibuang ke badan air.

Ada beberapa proses pengolahan limbah yang sudah banyak digunakan untuk mengolah limbah cair tempe, antara lain menggunakan biofilm, microbial fuel cell, dan fitotreatment. Fitotreatment merupakan suatu sistem pengolahan limbah menggunakan tanaman tertentu yang bekerjasama dengan mikroorganisme dalam media (tanah, koral dan air) sehingga dapat mengubah zat kontaminan (pencemar) menjadi kurang atau tidak berbahaya bahkan menjadi bahan yang berguna secara ekonomi [4]. Fitotreatment memiliki keuntungan dibandingkan dengan proses lainnya yaitu murah dari segi biaya, pengoperasian dan perawatan lebih mudah, mempunyai efisiensi yang cukup tinggi, dapat menghilangkan logam-logam berat, serta dapat memberikan keuntungan yang tidak langsung seperti mendukung fungsi ekologis .

Cyperus rotundus $L$ dan Scirpus grossus merupakan jenis tanaman yang biasanya banyak tumbuh di rawa. Jenis tanaman gulma seperti Cyperus rotundus L dan Scirpus grossus sering ditemui namun masih jarang ada yang melakukan penelitian terhadap gulma tersebut. Cyperus rotundus $L$ dan Scirpus grossus dipilih karena mudah didapatkan, dan banyak tumbuh di sekitar daerah pabrik tempe. Scirpus grossus digunakan dalam penelitian ini karena spesies ini potensial sebagai tumbuhan hiperakumulator [5] yaitu tumbuhan yang secara alami mampu mengakumulasi logam dalam jumlah besar pada tunas mereka [6].

Cyperus rotundus $L$ dapat menurunkan konsentasi BOD dan COD lindi pada hari ke-12 masing-masing sebesar $82,65 \%$ dan $73,38 \%$. Penelitian yang dilakukan oleh [7], waktu pemaparan yang optimal untuk pengolahan lindi menggunakan Scirpus grossus ialah 10 hari dengan menggunakan 8 tumbuhan. Pada pengolahan air limbah rumah tangga, Scirpus grossus dapat menurunkan kadar TSS sebesar 89,47\%, BOD 40,89\%, nitrit $48,32 \%$, dan sulfat $13,24 \%$ [8].

Pada penelitian ini limbah tempe berasal dari industri rumahan di daerah Rungkut, Kota Surabaya, Jawa Timur. Besarnya kadar $\mathrm{BOD}_{5}$, COD, TSS limbah cair tempe berturutturut adalah sebesar $19048 \mathrm{mg} / \mathrm{l}, 36000 \mathrm{mg} / \mathrm{l}, 1340 \mathrm{mg} / \mathrm{l}$ (limbah rebusan), untuk limbah rendaman sebesar $13158 \mathrm{mg} / \mathrm{l}, 26000$ 
mg/l, $1190 \mathrm{mg} / \mathrm{l}$, sedangkan $17021 \mathrm{mg} / \mathrm{l}, 32000 \mathrm{mg} / \mathrm{l}, 1275 \mathrm{mg} / \mathrm{l}$ untuk limbah campuran rebusan dan rendaman.

\section{METODE PENELITIAN}

Penelitian ini dilakukan di laboratorium dan ruang workshop Jurusan Teknik Lingkungan, ITS.

\section{A. Persiapan Alat dan Bahan}

Pada uji RFT digunakan ember berdiameter $30 \mathrm{~cm}$ yang diisi dengan media tanam pasir sedalam $20 \mathrm{~cm}$. Sementara bahanbahan yang digunakan dalam uji RFT adalah limbah cair tempe, tumbuhan Cyperus rotundus L., tumbuhan Scirpus grossus, pasir silika, serta bahan-bahan kimia yang diperlukan selama analisis.

\section{B. Analisis Karakter Sampel}

Sampel yang digunakan pada penelitian ini adalah limbah cair tempe yang berasal dari industri rumahan di daerah Rungkut, Kota Surabaya, Jawa Timur. Sampel diambil dari beberapa proses pengolahan tempe, yakni dari proses perebusan, perendaman dan campuran limbah rebusan dan rendaman. Parameter limbah cair tempe yang diukur dalam penelitian ini mengacu pada Pergub Jatim No.72 Tahun 2013 tentang baku mutu air limbah bagi industri dan/atau kegiatan usaha lainnya, yaitu BOD, COD, TSS, dan pH.

\section{C.Pelaksanaan Penelitian}

RFT dilakukan selama 7 hari. Pengamatan secara fisik dilakukan terhadap Cyperus rotundus L. dan Scirpus grossus. Variasi konsentrasi limbah yang digunakan adalah $0 \%$ (control), 10\%, 25\%, 50\%, 75\% dan 100\%. Limbah cair tempe diencerkan dengan air PDAM, dimasukkan ke dalam reaktor ember sebanyak 2 liter untuk tumbuhan Cyperus rotundus $L$. dan 3 liter untuk tumbuhan Scirpus grossus. Air yang ditambahkan ke dalam ember berbeda volume, dikarenakan perbedaan panjang tanaman dan panjang akar dari kedua tanaman tersebut. Demikian pula dengan jumlah tanaman yang ditanam di masing-masing ember berbeda disesuaikan densitas masing-masing jenis tumbuhan. Ember yang ditanami Cyperus rotundus $L$. berisi tiga tumbuhan dalam setiap reaktor. Sedangkan untuk tanaman Scirpus grossus dalam setiap reaktor adalah 4 tumbuhan. Tanaman yang digunakan dalam penelitian ini merupakan generasi kedua dari masing-masing tanaman.

\section{HASIL DAN PEMBAHASAN}

\section{A. RFT Cyperus rotundus $L$.}

Parameter karakteristik sampel limbah cair tempe pada bulan Mei 2017 yang dianalisa di Laboratorium Teknik Lingkungan ITS untuk semua jenis limbah cair tempe yaitu $\mathrm{BOD}_{5}(\mathrm{mg} / \mathrm{l})$, COD (mg/l), dan TSS (mg/l).

Uji RFT dilakukan untuk mendapatkan besarnya konsentrasi maksimum polutan yang memberikan efek pada tumbuhan namun tumbuhan masih dapat bertahap hidup.

Pada semua jenis limbah cair tempe (rebusan, rendaman, dan campuran) dengan konsetrasi $100 \%$ menyebabkan daun, batang dan akar semua tanaman menjadi berubah warna dari hijau menjadi kuning dan mongering dalam waktu 3 hari pengamatan. Hal ini menandakan tanaman tidak dapat tumbuh dan mulai mati selama rentang waktu RFT (sebelum 7 hari). Dalam 3 hari pengamatan yang sama, semua jenis limbah cair tempe dengan konsentrasi sebesar $75 \%$ dan $50 \%$ juga menyebabkan adanya perubahan warna pada daun tanaman, yaitu mulai menguning.

Setelah 7 hari pengamatan, tumbuhan yang terpapar limbah rendaman dengan konsentrasi $25 \%$ tidak menunjukkan adanya perubahan warna pada daunnya dan tumbuhan tetap tampak segar (Gambar 1). Hal yang sama juga ditunjukkan oleh limbah rebusan dan campuran dengan konsentrasi 10\%, Cyperus rotundus $L$ tidak menunjukkan adanya perubahan warna pada daun dan batang. Daun tumbuhan tetap segar dan berwana hijau terang (Gambar 2 dan 3).

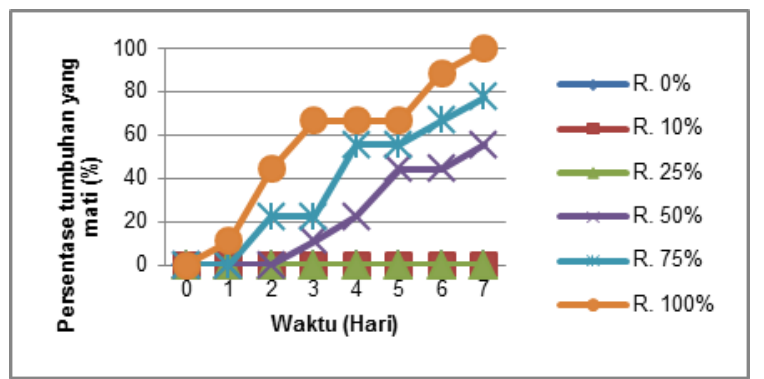

Gambar 1. Persentase Jumlah Tumbuhan Cyperus rotundus L.yang Mati oleh Paparan Limbah Rendaman Dalam 7 hari Pengamatan

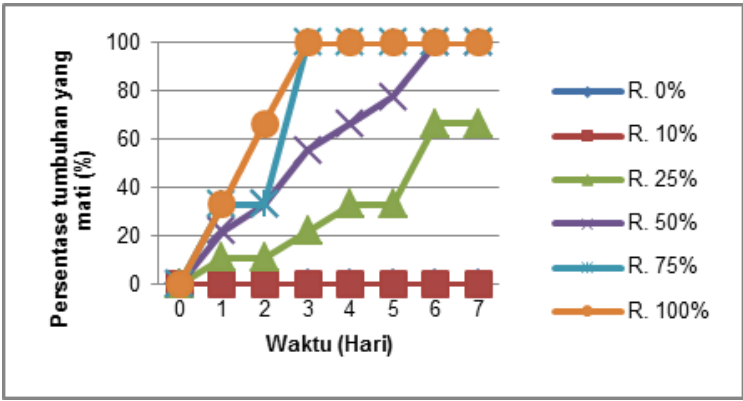

Gambar 2. Persentase Jumlah Tumbuhan Cyperus rotundus L.yang Mati oleh Paparan Limbah Rebusan Dalam 7 hari Pengamatan.

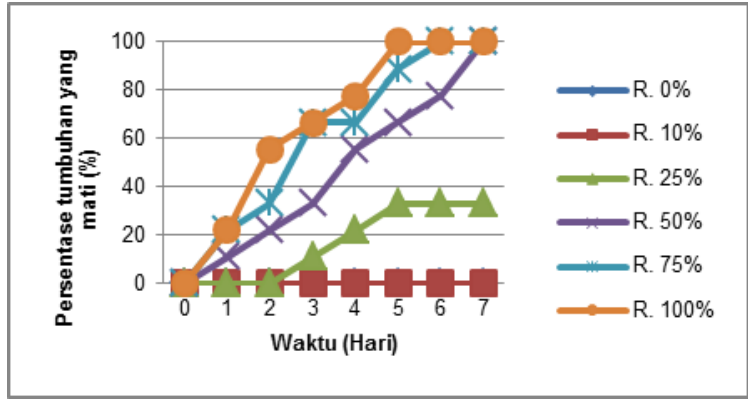

Gambar 3. Persentase Jumlah Tumbuhan Cyperus rotundus L.y ang Mati oleh Paparan Limbah Campuran Dalam 7 hari Pengamatan

Kematian tumbuhan Cyperus rotundus $L$ dapat dilihat pada warna daun dan batang tumbuhan yang rusak dibandingkan dengan tumbuhan pada reaktor kontrol. Dampak layu dan kering yang terjadi pada tumbuhan yang terpapar limbah 
dengan konsentrasi berlebih, menyebabkan tumbuhan mengalami kerusakan jaringan daun, daun menguning dan mengering, pertumbuhan batang terhambat dan terganggunya proses fotosintesis sehingga dapat menyebabkan efek kematian pada tumbuhan. Kondisi tumbuhan pada hari ke-20 dapat dilihat pada Gambar 4.

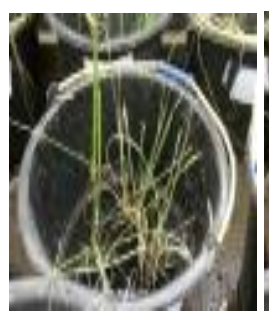

(a)

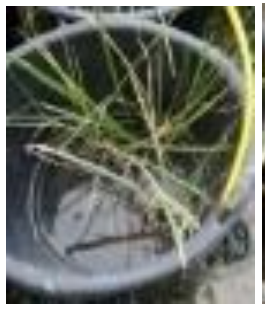

(c)

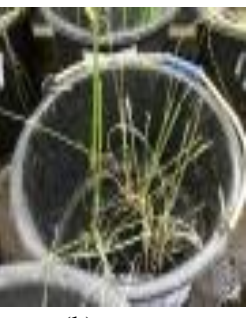

(b)

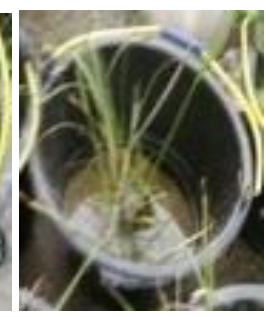

(d)
Gambar 4 Kondisi Tumbuhan pada hari ke- 20 pada (a) limbah rebusan, (b) limbah campuran, (c) limbah rendaman, dan (d) kontrol tumbuhan tanpa limbah.

\section{B. RFT Scirpus grossus}

Selain tumbuhan Cyperus Rotundus L,uji RFT juga dilakukan pada tumbuhan Scirpus grossus yang juga dipapari dengan limbah cair tempe berkonsentrasi 0\%, 10\%, 25\%, 50\%, $75 \%$, 100\%. Jenis limbah yang digunakan adalah limbah rebusan, rendaman, dan campuran. Volume limbah yang digunakan adalah 3 liter, jumlah koloni tumbuhan yang digunakan adalah 3 tumbuhan dalam setiap variasi konsentrasi. Tumbuhan dipapari limbah selama 7 hari.

Scirpus grosus yang dipapari limbah rebusan, rendaman, dan campuran dengan konsentrasi 100\% menunjukkan adanya perubahan warna pada daun, batang dan akar pada semua koloni. Dalam 2 hari pemaparan, warna tumbuhan berubah menjadi kuning dan mengering yang menandakan tumbuhan tidak dapat tumbuh dengan baik dan mulai mati. Dalam 2 hari pemaparan limbah rebusan, rendaman, dan campuran dengan konsentrasi $75 \%$ dan $50 \%$ juga menunjukkan adanya perubahan fisik pada daun tanaman. Perubahan itu adalah daun tampak layu dan menguning.

Tumbuhan yang terpapar limbah rebusan dan campuran dengan konsentrasi 25\%, menunjukkan adanya daun tanaman yang mulai layu dan mulai menguning setelah 4 hari pengamatan. Sedangkan tumbuhan yang terpapar limbah rendaman dengan konsentrasi yang sama, tanaman tetap tampak segar dan tidak terjadi perubahan.

Setelah pemaparan 7 hari dengan limbah rebusan dan campuran berkonsentrasi 10\%, tumbuhan tidak menunjukkan terjadinya perubahan fisik pada daun dan batang. Daun tumbuhan tetap segar dan berwana hijau terang (Gambar 5 dan 6). Begitu juga dengan konsentrasi $25 \%$ untuk jenis limbah rendaman, daun tumbuhan tetap segar dan berwarna hijau terang sama kondisinya seperti tumbuhan pada tumbuhan kontrol (konsentrasi limbah 0\%) (Gambar 7).

Oleh karena itu dapat dikatakan bahwa pada pemaparan limbah rebusan dengan konsentrasi 10\%, limbah campuran berkonsentrasi 10\%, dan limbah rendaman dengan konsentrasi $25 \%$, tumbuhan Scirpus grossus mampu bertahan hidup dan dapat digunakan pada tahap penelitian selanjutnya (fitotreatment).

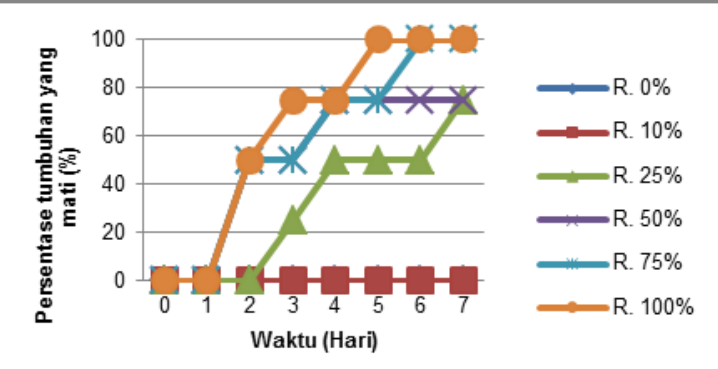

Gambar 5. Persentase Jumlah Tumbuhan Scirpus grosus yang Mati oleh Paparan Limbah Rebusan Dalam 7 hari Pengamatan

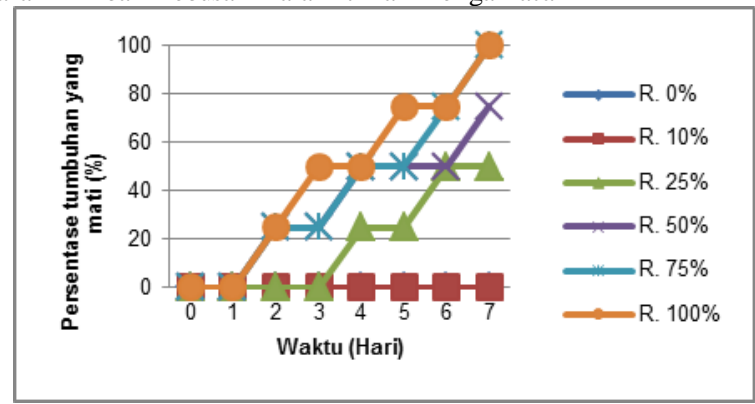

Gambar 6. Persentase Jumlah Tumbuhan Scirpus grosus yang Mati oleh Paparan Limbah Campuran Dalam 7 hari Pengamatan

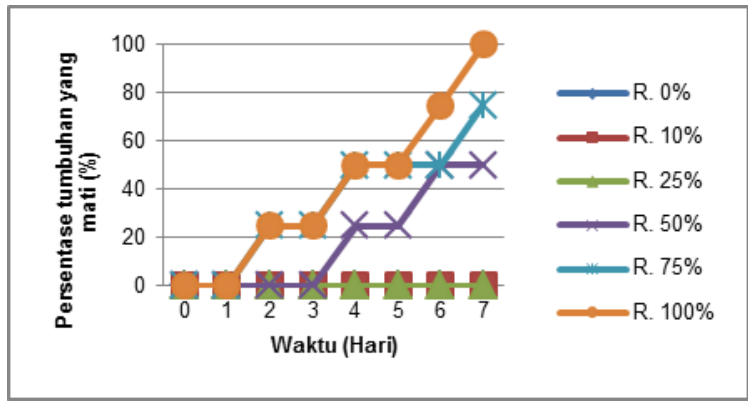

Gambar 7. Persentase Jumlah Tumbuhan Scirpus grosus yang Mati oleh Paparan Limbah Rendaman Dalam 7 hari Pengamatan.

Kondisi Scirpus grossus terhadap pemaparan limbah cair tempe selama 7 hari dapat dilihat pada Gambar 8 .

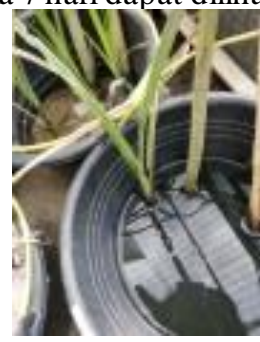

(a)

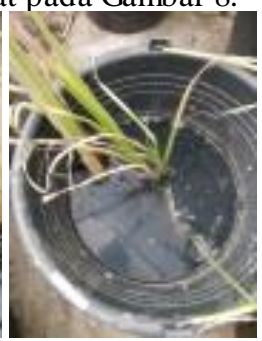

(b) 


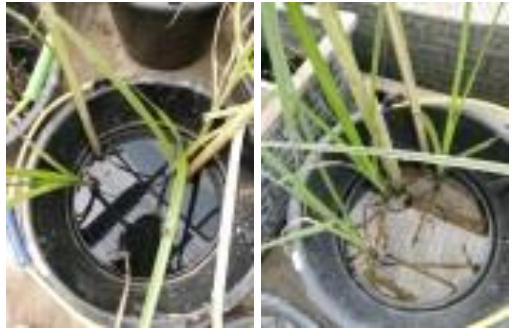

(c)

adalah untuk limbah rebusan dengan konsentrasi 10\%, limbah rendaman $25 \%$ dan untuk limbah campuran konsentrasi $10 \%$.

\section{DAFTAR PUSTAKA}

[1] Badan Ketahanan Pangan, "Roadmap Diversifikasi Pangan Tahun 2012-2014,” Jakarta, 2013.

[2] Nuraida, "Dalam Analisis Kebutuhan Air pada Industri Pengolahan Tahu dan Kedelai," Medan, 2014.

Gambar 8 Kondisi Tumbuhan Scirpus grossus pada Hari ke- 20 pada (a) Limbah Rebusan, (b) Limbah Campuran, (c) Limbah Rendaman, (d) Kontrol Tumbuhan Tanpa Limbah.

Berdasarkan pada Gambar 8, konsentrasi limbah yang tidak menyebabkan dampak pada tumbuhan adalah $10 \%$ untuk limbah rebusan, $10 \%$ untuk limbah campuran dan $25 \%$ untuk limbah rendaman tempe. Kematian tumbuhan Scirpus grossus dapat dilihat dari warna daun (kuning/ coklat) dan batang tumbuhan yang rusak dibandingkan dengan tumbuhan tanpa pemaparan limbah cair tempe (kontrol).

\section{KESIMPULAN}

Konsentrasi maksimum limbah cair tempe yang dapat diterima oleh tumbuhan Cyperus rotundus L. dan Scirpus grossus yang menunjukkan tumbuhan masih bertahan hidup

[3] E. Wiryani, "Analisis Kandungan Limbah Cair Pabrik Tempe," J. Sainteks, 2013.

[4] T. Sungkowo, S. Elystia, and I. Andesgur, "Pengolahan Limbah Industri Tahu Menggunakan Tanaman Typha latifolia dan Eceng Gondok dengan Metode Fitoremediasi," JOM FTEKNIK, vol. 2, 2015.

[5] B. V. Tangahu, S. R. Abdullah, H. Basri, N. Anuar, and M. Mukhlisin, "Enchancement of Caloric Value of Scirpus grossus After Phytotoxicity Test of Lead (Pb)," J. Revel. Sci., vol. 1, 2010.

[6] S. Mangkoedihardjo and G. Samudro, Fitoteknologi Terapan. Yogyakarta: Graha Ilmu, 2010.

[7] S. Rachmaulin, S. Mangkoedihardjo, "Pengaruh Waktu Pemaparan dan Jumlah Rumbuhan Terhadap Efisiensi Pengolahan Lindi TPA Sidoarjo," J. Tek. POMITS, vol. 1, 2013.

[8] F. Sari, "Fitoremediasi Limbah Rumah Tangga oleh Tanaman Wlingen (Scirpus grossus), Kiapu (Pistia stratiotes) dan Teratai (Nymphe firecrest)," Medan, 2013. 